\title{
Paris Agreement and the Regions Adapt Initiave: The Role of Transnational Action in the Adoption and Implementation of Climate Policies
}

\author{
Fernando Rei, Mariângela Mendes Lomba Pinho \\ Faculty of Law, Catholic University of Santos, Santos, Brazil \\ Email address: \\ fernandorei@ig.com.br (F. Rei), mariangelamlp@unisantos.br (M. M. L. Pinho)
}

\section{To cite this article:}

Fernando Rei, Mariângela Mendes Lomba Pinho. Paris Agreement and the Regions Adapt Initiave: The Role of Transnational Action in the Adoption and Implementation of Climate Policies. International Journal of Science, Technology and Society. Vol. 5, No. 4, 2017, pp. 91-96. doi: $10.11648 /$ j.ijsts.20170504.16

Received: May 22, 2017; Accepted: June 14, 2017; Published: June 27, 2017

\begin{abstract}
The Paris Agreement reaffirms the important role of non-Party stakeholders in climate action. This article examines the outcomes of paradiplomatic action undertaken in the adoption and implementation of adaptation climate policies by subnational governments, introducing the Regions Adapt Initiative. The great differential in this project is that this was the first global initiative specifically focused on the theme adaptation. Over the past few decades, a number of initiatives have been implemented to mitigate climate change, but is necessary to go a bit further and take action to adapt to current and future conditions to ensure sustainable development. In some parts of the world the State has already demonstrated that they are not able to act effectively in this segment and this space has been occupied by subnational actors, who become important agents in international relations. While paradiplomacy influenced the adoption of the subnational climate change policies, the ensuing steps necessary for implementing this policy has a significant transnational engagement.
\end{abstract}

Keywords: Paris Agreement, Transnational Climate Action, Subnational Climate Policy, Environmental Paradiplomacy, Regions Adapt Initiative

\section{Introduction}

The 21st Conference of the Parties to the United Nations Framework Convention on Climate Change (UNFCCC) resulted in the adoption of a Paris Agreement. The Paris Agreement reaffirms the important role of non-Party stakeholders in climate action. Climate change is a global issue, but its impacts are felt mostly on a regional and local scale. The challenge of addressing these impacts through adaptation requires not only the commitment of nation states, but a multi-stakeholder approach. Subnational governments, representatives from different sectors of the economy and members of the civil society participated in the Summit and in public demonstrations to demand immediate action. These stakeholders convened to influence national leaders in acknowledging the importance of engaging non-State actors in climate action.

Certainly the Paris Agreement represented the main progress in the negotiations that have been established so far, with themes reaffirming multilateralism and replacing the Convention's only legal instrument, the Kyoto Protocol, which does not meet expectations of climate change. In sum, COP21's greatest contribution was to go further, focusing on reducing emissions, mitigating and advocating for adaptation actions, which were little explored in previous COPs, as well as the recognition of the role of subnational governments. In this way, the Agreement does indeed break new ground in international climate policy [1].

The interest of non-State actors in the outcomes of negotiations is another indication that the governance of climate change occurs simultaneously at multiple levels. Responses to the problem of climate change are formulated not only through intergovernmental, as well as by transnational and subnational processes. Transnational climate governance occurs when cities, companies, nongovernmental organisations (NGOs), and other sub- and nonstate actors coordinate across borders to govern climate change. Attempts to map transnational climate governance 
have identified that between 60 and 75 transnational climate 'institutions', 'initiatives' or 'experiments' introduced since the 1990s [2], [3], [4].

Subnational governments and networks of them acting transnationally to address climate change receive particular attention in the literature on transnational climate governance. The proliferation of voluntary subnational action during the past decade reveals the multiple levels - local, regional, national, transnational and global - involved in climate governance [5]. Moreover, the transnational action undertaken by subnational governments to address climate change can be understood as a form of paradiplomatic activity. In recent years the term paradiplomacy started being used to describe the international activities of subnational governments in the formation and implementation of climate policy [6], [7], [8].

Subnational governments have an important and strategic roles to play in addressing climate change and ensuring concrete results of adaptation actions, because have authority over key aspects of climate policy, including energy, transportation, and the build environment.

As the overall global environmental quality has continually declined and for Banks [9]" with the scarcity of natural resources, it is very likely that only the strong or smart or both - or those who are protected by the strong or smart or both - are going to feel really comfortable", climate policies issues can have a considerable influence, therefore is urgent to promote the initiatives that can support positively.

This article contributes to the literature with an analysis of the interactions between transnational and subnational initiatives in the development of climate policies, in particular introducing the Regions Adapt initiative, a new global commitment to support and report efforts on adaptation at the state and regional level.

\section{The Literature of Paradiplomacy and Climate Change}

The transnational aspect of climate change governance has been the object of increasing academic attention. Studies on the international participation of sub- and non-state actors are found in the dominions of international relations [10], [11], [12], [13] international law [14], [15] and other social sciences such as sociology and geography [16], [17]. Thanks to this multidisciplinary approach, the literature covers diverse understandings of transnational climate governance.

Globalization is a phenomenon that puts in crisis the theory of modern sovereignty, encouraging their reconfiguration, contributing to the magnitude of the problems being potentialized and it was a natural consequence for the emergence of paradiplomacy [18], [19], [20].

Alongside private actors, scholarship of transnational climate governance has paid particular attention to the participation of subnational governments in transnational climate governance. Researchers examine the emergence of regions, and networks of regions, like nrg4SD - Network of Regional Governments for Sustainable Development, acting transnationally to address climate change.

In this case, the international activities of subnational governments in the formation and implementation of climate policy is described as a form of paradiplomacy. that covers a variety of formats and for Soldatos [21] it is the result of factors such as regionalization of the economy, the advancement of communications, democratization actions, among others. Keating [22] argues that paradiplomacy is inherently a pluralistic activity, with the involvement of several actors and dependent on the capacity of integration between them to achieve the objectives outlined. Rei et al. [23] suggest that environmental paradiplomacy is helping to establish the relevance of subnational governments' participation in the governance of climate change. Abbott [24] suggests that transnational climate governance enables institutions and networks to penetrate national governments at multiple levels.

\section{The Nrg4sd and the Regions Adapt Initiative}

The Network of Regional Governments for Sustainable Development, nrg4SD is a global network that represents solely regional governments in the fields of climate change, biodiversity and sustainable development. It was established in 2002, at the World Summit in Johannesburg, and today has over 56 members from 28 countries in 4 continents.

The main objectives of the network are:

1. To promote sustainable development at the level of regional governments around the Globe.

2. To act as the voice and representative of regional governments at global level in the field of sustainable development.

3. To seek a wider recognition at international level of the importance of regional governments towards sustainable development.

4. To contribute to the elaboration and implementation of responsible and ambitious territorial policies, actions, tools and resources, adapted to the regional level.

5. To encourage expertise exchange, cooperation projects and partnerships among our members, as well as between them and other major international stakeholders.

The participation of subnational governments has been growing in international relations and the creation of nrg4SD encourages the proposition of international discussions related to sustainable development. It is a form of environmental paradiplomacy that strengthens climate governance. For Bruyninckx et al [25], the differential of this network was to present "a North-South scope and a focus on United Nations agencies". Still in the nrg4sd context, the network acting as an umbrella has several initiatives under its support, among them the innovative Regions Adapt.

According to the IPCC [26], adaptation to climate change 
is a process of adjustment not only to the current climate but mainly to the future and its effects, therefore. "In human systems, adaptation seeks to moderate or avoid harm or exploit beneficial opportunities. In some natural systems, human intervention may facilitate adjustment to expected climate and its effects", so the adaptation aims to promote the reduction of vulnerability through climate risk management.

Without adaptation actions there is no way to deal with the climate impacts and for the adaptation to be successful it requires a systemic view with multiple actors, which all stakeholders, at different levels of government and is this case the exchange of experiences is essential so that together they can try to reverse possible catastrophes.

Subnational governments play a fundamental role to enhance coordination and cooperation across all levels of governments [27] to improvement policy consistency, and to ensure concrete results of adaptation actions. In other words, subnational governments are a key nexus between national and local governments and can therefore be quite helpful when turning national strategies and policies to the local level.

Because adaptation is typically described as locationspecific, recognized by the Paris Agreement considerations, adaptation strategies need to take into account the territories where adaptation challenges should be tackled.

In this regard, regional governments can play a significant role [28]. They are key players on the ground to limit and efficiently tackle climate change, since $50 \%$ to $80 \%$ of adaptation and mitigation actions are or will be implemented at the regional or local level [29]. Therefore the Regions Adapt Initiative sheds light upon one of the great challenges of climate change: the issue of adaptation.

Adaptation actions need political support and must be integrated with the sectoral policies that must consider the impacts of climate change in the planning process and which are often not developed due to the lack of scientific knowledge [30].

Although practically all the continents are covered by the initiative, the total population of the participants presents a representation of around $2 \%$ of the world population; therefore, it can be observed that there is still much space for the initiative to grow with the increase of other sub-state and non-state actors.

However, international support and collaboration for regional action on adaptation remains underexplored. While many subnational governments have already developed longterm adaptation strategies and innovative solutions to increase climate resilience, a number of on-going limitations and challenges limit their ability to respond effectively. These include infrequent financial and human resources, lack of integration and coordination between levels of government, insufficient management practices, research and tools to monitor adaptation effectiveness, and, critically, the lack of medium to long-term adaptation planning [31].

In this scenario, emerges the Regions Adapt Initiative, a new global commitment to support and report efforts on adaptation at the state and regional level. On the initiation of
Rio de Janeiro and Catalonia, this initiative purposes to establish a cooperative framework for regions - Australian Capital Territory (Australia), Azuay (Ecuador), Basque Country (Spain), British Columbia (Canada), California (USA), Catalonia (Spain), Ceará (Brazil), Fatick (Senegal), Goiás (Brazil), Gossas (Senegal), Jalisco (Mexico), KwaZulu-Natal (South Africa), Lombardia (Italy), Parana (Brazil), Prince Edward Island (Canada), Québec (Canada), Rio de Janeiro (Brazil), Rio Grande do Sul (Brazil), Saint Louis (Senegal), São Paulo (Brazil), South Australia (Australia), Sud-Comoé (Ivory Coast), Tocantins (Brazil), Tombouctou (Mali), Vermont (Canada), Wales (UK), Western Province (Sri Lanka) - to exchange experiences and best practices on their actions and challenges when adapting to climate change [32].

By participating, state and regional government promise to collaborate, exchange knowledge and share best practice policy models that foster adaptation and resilience to climate change, pursuing multidimensional and innovative methods. This commitment includes adopting or reviewing plans on adaptation within two years, to implement an adaptation action in one of a series of thematic areas, as well as to report on the progress of the adaptation initiatives through the Compact of States and Regions platform.

Recognizing that legal responsibility as well as technical and financial capacities varies usually among different jurisdictions, the participants of the Regions Adapt initiative commit to join efforts to improve the effectiveness of subnational governments in adapting to climate change. With this aspiration, the Participants express their intention to:

1. Adopt a strategic approach to adaption and prioritize adaptation actions, e.g., through adopting or reviewing a regional plan or strategy on climate change adaptation within two years of joining the initiative;

2. Take concrete action on adaptation in at least one of the key priority areas identified by the regions. These could include: water resources and management; resilience and disaster risk reduction; agriculture and zootechnics; forestry, protected areas and biodiversity; infrastructure (including transport and the energy sectors) and territorial planning; economic impacts and opportunities; social adaptation and impacts;

3. Report data on the progress of the adaptation actions on an annual basis through the Compact of States and Regions reporting platform. As an international cooperation initiative, Regions Adapt aims to provide a framework to facilitate and support collaboration between state and regional governments and other relevant international partners, undertaking joint efforts based on solidarity principles. Nevertheless, with a view to the particular circumstances and capacities of each Participant, it is fundamental they have own specific plans tailored for their territorial priorities and reality.

By joining the initiative, regional governments also commit to reporting data on the progress of the adaptation actions on an annual basis through the "risks and adaptation".

The concept of Regions Adapt is based on the principles of 
synergy, building with other organizations; the initiative is supported by The Climate Group and open to any participant, at local or regional level, regardless of the level of policy for climate change.

In fact, sharing their policies and programs, the participants encourage other governments to learn from their experiences, exchange ideas on further improvements and create common knowledge on how to adapt to a changing climate, in a network environment, dynamic and with an effective opportunity for participation and dialogue.

In order to meet the objectives of the initiative, which is to promote cooperation and dissemination of knowledge, Working Groups were established, according to the seven areas considered as key priorities, being stimulated to explore one or more of the following themes:

1. Modeling and evaluation of climatic impacts;

2. Planning for adaptation to climate change;

3. Construction of metrics and indicators;

4. Financing and support to adapt to climate change;

5. Adaptation of the state / region / province.

Working with cross-cutting themes the initiative seeks synergy among working groups. The first four working groups were constituted in March 2016 and present the following topics: water resources and management; resilience and disaster risk reduction; agriculture and zootechnics; forestry, protected areas and biodiversity; economic impacts and opportunities.

Considering that mitigation actions are much more costly than adaptation actions, especially in developing countries due to the scarcity of resources, adaptation actions need to be prioritized. In mitigation actions the risks are much greater and significant losses. In this way, the more knowledge, the greater the chances of success in combating climate change.

Despite the efforts of many regional governments to overcome difficulties and implement new projects, the initiative is new, but begins to build a history that can be used by other regional governments, helping to speed up processes, reduce costs and avoid repeating mistakes in actions that have been previously implemented. It is clear that the specific characteristics and conditions of each region will always require a more critical analysis but have parameters of comparison to help managers in decision making for a more accurate evaluation.

Subnational governments need to prepare for the impacts of climate change and one of the contributions of the Regions Adapt is to initiate the process by describing the level of risk and the timescale for its occurrence. The initiative have been presenting metrics for risk classification and expected timescales in terms of vulnerability climate change.

Nowadays, although for some regional governments, adaptation is somehow an pratic already implemented, in order hand, some subnational states did not even begin to work on this subject, confirming the possibility of growth of the initiative.

In the first report [33], all of the regional governments that reported through the Compact of States and Regions Platform said that the impacts of climate change present significant physical risks to their territories. This report - Regions Adapt 2016 Report: An assessment of risks and actions - offers an overview of the different physical risks they are facing from climate change and how they are taking action to anticipate these impacts. It is stated in the report that $50 \%$ to $80 \%$ of adaptation and mitigation actions are or will be implemented at regional or local level". A relevant contribution of the report is the presentation of recommendations for the future, encouraging their implementation "before 2020 to take advantage of the Paris Agreement's entry into force, considering regional governments the main agents to effectively combat climate change, the ten recommendations are:

1. Carry out vulnerability assessments to understand physical, social and economic vulnerability to climate change and to identify adaptation measures.

2. Develop a strategic approach to adaptation and prioritize adaptation actions.

3. Take concrete action on adaptation in at least one of the key priority areas identified through RegionsAdapt.

4. Foster citizen and community engagement in your region to develop and implement sustainable adaptation actions.

5. Build lasting relationships with your regional industries to learn why adaptation matters to them.

6. Engage your national government in dialogue to support the implementation of integrated National Adaptation Plans and policies.

7. Integrate climate change and adaptation as a crosscutting topic in your sectoral policies.

8. Exchange and learn from other regions worldwide.

9. Mobilize finance for climate change adaptation from public and private sources.

10. Report data on your adaptation actions on an annual basis and track your progress.

Based on the aforementioned considerations, and the suggestions of Nayanananda Nilwala [34], climate adaptation is fundamental, emphasizing that the Regions Adapt initiative can preserve the biodiversity in its territories and help in the accomplishment of the SDGs related to the action plan of each region, with nine objectives (SDGs) can be directly related to the actions of the initiative.

As described, the majority of the disclosing governments has already carried out a vulnerability assessment, or has one in progress. This indicates that regional governments are well aware of the need to prepare for the impacts of climate change, and this kind of assessment is the first step to identify their needs.

The dissemination of the actions taken by the regional governments emphasize that the sharing of experiences can present possible solutions to be replicated. However, the evidence shows that only with adaptation actions will it not be possible to stop the climate change process, or often goes unrecognized, because only with a change in social behavior will we have a greater commitment and understanding of the situation.

Finally, were highlighted in the Regions Adapt 2016 
Report that climate change does not only physical but socioeconomic risks, especially in the underdeveloped countries that also face challenges in their own backyard, such as the scarcity of financial resources, that is the major problem.

\section{Conclusion}

Although adaptation has become a mainstream topic within the global regime on climate change, there still remains a gap between mitigation and adaptation that has yet to be fully surmounted. This is why the UNFCCC has constantly called for improved action on adaptation.

Based on these circumstances, a collective understanding has developed - indicating that regional governments needed to take a global action on climate adaptation.

By fulfilling the aforementioned gap, Regions Adapt became the first global initiative intended to inspire and support regional governments to take concrete action, collaborate and report efforts on climate change adaptation.

Regional governments are encouraged to implement and develop the Initiative as soon as possible in order to collaborate with the Paris Agreement's entry into force.

After one year of the Regions Adapt initiative, with the first round of the reporting process on the progress of adaptation actions, it is inspiring to see the commitment that regional governments within the initiative are taking to address the issue of climate change adaptation.

\section{References}

[1] Pinho. Mariângela Mendes L. Paradipomacia Ambiental e Econômica no Regime Internacional de Mudanças Climáticas: a iniciativa Regions Adapt. Thesis presented in the Doctoral Program in International Environmental Law at the Catholic University of Santos. Brazil, 2017.

[2] Bulkeley, Harriet. Reconfiguring environmental governance: towards a politics of scales and networks. Political Geography, 24 (8), 2005, p. 875-902.

[3] Hale, Thomas, \& Roger, Charles. Orchestration and transnational climate governance. The Review of International Organizations, 9 (1), 2014, p. 59-82.

[4] Hoffmann, Matthew J. Climate governance at the crossroads: experimenting with a global response after Kyoto. Oxford: Oxford University Press, 2011.

[5] Andonova, Liliana B., \& Mitchell, Ronald B. The rescaling of global environmental politics. Annual Review of Environment and Resources, 35 (1), 2010, p.255-282.

[6] Chaloux, Annie, \& Paquin, Stéphane. Green paradiplomacy in North America: successes and limits of the NEG-ECP. In Hans Bruyninckx, Sander Happaerts \& Karoline Van den Brande (Eds.), Sustainable development and subnational governments policy making and multi-level interactions. Hampshire: Palgrave Macmillan, 2012, p.217-236.

[7] Eatmon, Thomas D. Paradiplomacy and climate change: American states as actors in global climate governance. Journal of Natural Resources Policy Research, 1 (2), 2009, p. 153-165.
[8] Rei, Fernando, Cunha, Kamyla Borges da, \& Setzer, Joana. La paradiplomacia ambiental en la nueva gobernanza internacional. TIP - Trabajos de Investigacion en Paradiplomacia, 2, 2012.

[9] Banks, Ferdinand E. Energy and Economic Theory. World Scientific Series on Environmental and Energy Economics and Policy - Vol 9. Singapore: World Scientifc Publishing, 2015.

[10] Abbott, Kenneth. The transnational regime complex for climate change. Environment and Planning C: Government and Policy, 30 (4), 2012, p.571-590.

[11] Andonova, Liliana B., Betsill, Michele M., \& Bulkeley, Harriet. Transnational climate governance. Global Environmental Politics, 9 (2), 2009, p.52-73.

[12] Falkner, Robert, Stephan, Hannes, \& Vogler, John. International climate policy after Copenhagen: towards a 'building blocks' approach. Global Policy, 1 (3), 2010, p.252262.

[13] Lidskog, Rolf, \& Elander, Ingemar. Addressing climate change democratically. Multi-level governance, transnational networks and governmental structures. Sustainable Development, 18 (1), 2010, p.32-41.

[14] Abbott, Kenneth W. Strengthening the Transnational Regime Complex for Climate Change. Transnational Environmental Law, FirstView, 2013, p.1-32.

[15] Heyvaert, Veerle. What's in a name? The covenant of mayors as transnational environmental regulation. Review of European, Comparative \& International Environmental Law, 22 (1), 2013, p.78-90.

[16] Bulkeley, Harriet. Reconfiguring environmental governance: towards a politics of scales and networks. Political Geography, 24(8), 2005, p. 875-902.

[17] Giddens, Anthony. The politics of climate change. Cambridge: Polity, 2009.

[18] Pinho. Mariângela Mendes L. Paradipomacia Ambiental e Econômica no Regime Internacional de Mudanças Climáticas: a iniciativa Regions Adapt. Thesis presented in the Doctoral Program in International Environmental Law at the Catholic University of Santos. Brazil, 2017.

[19] Gonçalves, Alcindo. Soberania, globalização e direitos humanos. In: Derani, Cristiane; Costa, José A. Fontoura (Coord.), Globalização e soberania. Curitiba: Juruá, 2004.

[20] Tavares, Rodrigo. Paradiplomacy: Cities and States as Global Players.Oxford University Press: United States of America, 2016.

[21] Soldatos. Panayotis. Cascading subnational paradiplomacy in an interdependente and transnational world. In Brown, Douglas; FRY, Earl (eds.). States and provinces in the internacional economy. Los Angeles: Institute of Governmental Studies Press, University of California, 1993.

[22] Keating, Michael. Regiones y assuntos internacionales: motivos, oportunidades y estratégias. In: Aldecoa, Francisco e Keating, Michael (eds.) Paradiplomacia: las relaciones internacionales de las regiones. Madrid: Marcial Pons/Ediciones jurídicas y sociales, 2000. 
[23] Rei, Fernando, Cunha, Kamyla Borges da, \& Setzer, Joana. La paradiplomacia ambiental en la nueva gobernanza internacional. TIP - Trabajos de Investigacion en Paradiplomacia, 2, 2012.

[24] Abbott, Kenneth. The transnational regime complex for climate change. Environment and Planning C: Government and Policy, 30 (4), 2012, p.571-590.

[25] Bruyninckx, Hans; Happaerts, Sander; Van Den Brande, Karoline. Sustainable Development and Subnational Governments: policy making and multi-level interactions. Macmillan Publishers, 2012.

[26] IPCC: Summary for Policymakers. In: Climate Change 2013: The Physical Science Basis. Contribution of Working Group I to the Fifth Assessment Report of the Intergovernmental Panel on Climate Change.Cambridge University Press, Cambridge, United Kingdom and New York, NY, USA, 2013.

[27] Bauer, A.; Steurer, R. Innovation in climate adaptation policy: are regional partnerships catalysts or talking shops? In: Environmental Politics, vol. 23, No. 5, 2014, p.818-838.

[28] NRG4SD. Inspiring subnational climate action. Cases and lessons from regional governments. Retrieved from http://www.nrg4sd.org/wp-content/uploads/2015/11/nrg4SDCases-NEW_web.pdf.
[29] NRG4SD. Inspiring subnational climate action. Cases and lessons from regional governments. Retrieved from http://www.nrg4sd.org/wp-content/uploads/2015/11/nrg4SDCases-NEW_web.pdf.

[30] Isoard, S. Perspectives on adaptation to climate change in Europe. In: ford, J. D.; Berrang-Ford, L. (eds.). Climate change adaptation in developed nations - from theory to practice. London / New York: Springer, 2011.

[31] NRG4SD. Inspiring subnational climate action. Cases and lessons from regional governments. Retrieved from http://www.nrg4sd.org/wp-content/uploads/2015/11/nrg4SDCases-NEW_web.pdf.

[32] NRG4SD. Inspiring subnational climate action. Cases and lessons from regional governments. Retrieved from http://www.nrg4sd.org/wp-content/uploads/2015/11/nrg4SDCases-NEW_web.pdf.

[33] NRG4SD. Regions Adapt 2016 Report: An assessment of risks and actions. Retrieved from http://www.nrg4sd.org/wpcontent/uploads/2017/01/RA2016REPORT_FINAL-1.pdf.

[34] NILWALA, N. Regions Adapt Iniciative: A key driver of SDGs Implementation. SDG Knowledge Hub, 2017. Retrieved from http://sdg.iisd.org/commentary/guestarticles/regionsadapt-initiative-a-key-driver-of-sdgsimplementation/. 